\title{
ANALISIS KERAGAMAN DAN KEKERABATAN KACANG TUNGGAK (Vigna unguiculata L) GENERASI M2
}

\author{
Yukarie Ayu Wulandari ${ }^{1}$, Sobir $^{2 *}$, Syarifah Iis Aisyah ${ }^{2}$ \\ ${ }^{1}$ Program Studi Aroteknologi Fakultas Pertanian Universitas Muhammadiyah Jakarta Jl. \\ KH. Ahmad Dahlan, RW.2, Cireundeu, Kec. Ciputat Tim., Kota Tangerang Selatan, \\ Daerah Khusus Ibukota Jakarta 15419, Indonesia \\ ${ }^{2}$ Departemen Agronomi dan Hortikultura Fakultas Pertanian Institut Pertanian Bogor Jl. \\ Meranti Babakan Dramaga Bogor 16680, Indonesia \\ *Email : rsobir@yahoo.com
}

Diterima: 03/07/2020

Direvisi: 07/07/2020

Disetujui: 07/07/2020

\begin{abstract}
ABSTRAK
Kacang tunggak ( $V$. unguiculata $\mathrm{L}$ ) memiliki potensi besar sebagai bahan pangan yang bergizi sebagai bahan pengganti kacang kedelai karena mengandung protein yang cukup dan kadar lemak rendah. Keragaman kacang tunggak rendah sehingga pelu dilakukan upaya peningkatan keragaman melalui induksi mutasi iradiasi sinar gamma. Penelitian dilaksanakan di kebun percobaan PKHTt Pasir Kuda IPB pada bulan Februari - Mei 2018 dengan menggunakan Rancangan Perbesaran dalam Rancangan Kelompok Lengkap Teracak (Augmented RKLT). Penelitian dilaksanakan dengan menggunakan 90 genotip mutan putatif generasi M2 sebagai genotip uji dan genotip KM4 sebagai pembanding yang diulang 10 kali. Hasil penelitian menunjukkan bahwa mutan putatif hasil induksi mutasi iradiasi sinar gamma dapat meningkatkan keragaman pada karakter kualitatif dan kuantitatif kacang tunggak. Keragaman genetik yang tinggi ditunjukkan pada karakter tinggi tanaman, periode panen, jumlah biji/polong dan berat biji/tanaman kacang tunggak dan nilai heritabilitas arti luas yang tinggi dihasilkan pada karakter panjang tangkai, umur berbunga, jumlah biji/polong dan berat biji/tanaman kacang tunggak. Hasil analisis kekerabatan menunjukkan tiga belas genotip mutan putatif yang berbeda dengan genotip KM4 yaitu genotip T6599P, T8028P, T7525P, T7551P, T7520P, T6574P, T6533P, T7058P, T6577P, T6591P, T7062P, T7069P dan T6561
\end{abstract}

Kata kunci: Heritabilitas, iradiasi sinar gamma, kekerabatan, mutan putatif

\section{ABSTRACT}

Cowpea (V. unguiculata $L$ ) has great potential as a nutritious food as a substitute for soybeans because it contains sufficient protein and low fat content. The diversity of cowpea is low so that need to increase diversity through the mutation induction of gamma ray irradiation. The study was carried out in the experimental garden of Pasir Kuda PKHT of IPB in February - May 2018 using a design of augmented in the Complete Group Design in a Randomized. The study was carried out using 90 putative mutant genotypes of M2 generation as the test genotype and KM4 genotype as a comparison which was repeated 10 times. The results showed that the M2 generation putative mutants showed diversity in the qualitative and quantitative characters of cowpea. High genetic diversity is shown in the character of plant height, harvest period, number of seeds / pods 
and weight of cowpea seeds / plants and high broad mean heritability values obtained on the character of stem length, flowering age, number of seeds / pods and weight of beans / plant nuts arrears. The result of kinship analysis showed thirteen different putative mutant genotypes with KM4 genotypes, namely T6599P, T8028P, T7525P, T7551P, T7520P, T6574P, T6533P, T7058P, T6577P, T6591P, T7062P, T7069P and T6561.

Keywords: Gamma ray irradiation, heritability, kinship, putative mutant

\section{PENDAHULUAN}

Kacang tunggak (V. unguiculata $\mathrm{L}$ ) memiliki potensi besar sebagai bahan pangan yang bergizi sebagai bahan pengganti kacang kedelai. Kandungan protein kacang tunggak sebesar 25,53\% (BKPPP 2014). Keunggulan kacang tunggak adalah memiliki kadar lemak yang lebih rendah dari kedelai sehingga dapat meminimalisasi efek negatif dari penggunaan produk pangan berlemak (Rosida et al. 2013). Asam amino yang penting dari protein kacang tunggak adalah kandungan asam amino lisin, asam aspartat dan glutamat (Chavan et al. 1989).

Kacang tunggak merupakan tanaman menyerbuk sendiri dimana genotip yang terbentuk homozigot, sehingga perlu dilakukan upaya untuk meningkatkan keragaman. Mutasi buatan dapat dipakai untuk meningkatkan keragaman genetik dalam pembentukan varietas unggul baru. IAEA (2003) menyatakan bahwa penelitian pemuliaan mutasi pada tanaman pertanian umumnya menggunakan iradiasi sinar gamma karena iradiasi sinar gamma memiliki daya tembus yang lebih dalam pada target sel dari material tanaman yang diinduksi.

Perbaikan karakter melalui program pemuliaan tanaman membutuhkan banyak informasi antara lain tentang keragaman genetik dan heritabilitas (Syukur et al. 2010). Nilai duga heritabilitas suatu karakter perlu diketahui untuk menentukan apakah karakter tersebut lebih banyak dipengaruhi oleh faktor genetik atau lingkungan (Yunianti et al. 2010). Nilai heritabilitas yang tinggi berarti faktor keragaman genetik berperan penting dalam penampilan fenotip pada tanaman (Ishak 2012). Penelitian dilaksanakan untuk mendapatkan informasi mengenai keragaan, keragaman genetik dan heritabilitas genotip mutan kacang tunggak generasi M2.

\section{METODE}

Penelitian dilaksanakan di Kebun Percobaan PKHT Pasir Kuda Institut Pertanian Bogor yang berada pada ketinggian $250 \mathrm{~m}$ dpl. Penelitian dilaksanakan pada bulan Februari sampai Mei 2018. Bahan genetik yang digunakan terdiri dari 90 genotip mutan putatif hasil panen generasi M1 sebagai genotip uji yaitu T8014, T6511, T7010, T7006, T6506, T6516, T7025, T7521, T6578, T7027, T6534, T8004, T6570, T6599, T8028, T8526, T7525, T7551, T7542, T6592, T7520, T7051, T8524, T8514, T6574, T6565, T8516, T7538, T6529, T7038, T6533, T6550, T7047, T7058, T7045, T7044, T6577, T7041, T7040, T6562, T6559, T6560, T6561, T6576, T6595, T6524, T7050, T7060, T6585, T6518, T7543, T7057, T6594, T7064, T7062, T8064, T8523, T8529, T8521, T8527, T8059, T8517, T8062, T6586, T8053, T8060, T7552, T6510, T7554, T6511, T8067, T6583, T8531, T7546, T7014, T8533, T7066, T7055, T7049, T6590, T8054, T6530, T6591, T6597, T6571, T7553, T7069, T7056, T7550, T6503 dan genotip KM4 sebagai pembanding. Penelitian dilaksanakan menggunakan Rancangan Perbesaran dalam Rancangan Kelompok Lengkap Teracak (Augmented RKLT). Genotipe uji ditanam tanpa ulangan, dan genotip pembanding diulang sepuluh kali. Setiap satuan percobaan terdiri dari 10 tanaman 
sehingga total terdapat 1000 tanaman percobaan.

Menurut Federer (1994) model matematik yang digunakan adalah :

Ket:

$$
Y i j=(\mu+\beta i+\tau j+\varepsilon i j) n_{i j}
$$

Yij = nilai pengamatan pembanding ke-i genotipe ke-j

$\mu=$ rataan umum

$\beta \mathrm{i}=$ pengaruh utama pembanding ke-i

$\tau \mathrm{j}=$ pengaruh genotipe ke- $\mathrm{j}$

$\varepsilon i j=$ pengaruh galat perlakuan pembanding ke-i ulangan ke-j $\mathrm{n}_{\mathrm{ij}}=$ nilai 1 bila perlakuan ke-j terletak pada kelompok ke-i dan bila perlakuan ke-j tidak terletak pada kelompok ke-i

Analisis sidik ragam dapat diduga dengan dua cara, yaitu berdasarkan populasi mutan yang ditanam dan berdasarkan model rancangan percobaan yang digunakan. Sidik ragam berdasarkan populasi mutan yang ditanam ditampilkan pada Tabel 1 . Sidik ragam model rancangan perbesaran dalam RKLT menurut Syahril (2018) ditampilkan dalam Tabel 2.

Tabel 1. Sidik ragam berdasarkan populasi yang ditanam

\begin{tabular}{llll} 
Sumber keragaman & $\mathrm{Db}$ & KT & $\begin{array}{l}\text { Nilai harapan } \\
\mathrm{E}(\mathrm{KT})\end{array}$ \\
\hline Blok & $\mathrm{r}-1$ & & \\
Genotipe & $\mathrm{g}-1$ & $\mathrm{M} 2$ & $\sigma^{2} \mathrm{e}+\sigma^{2} \mathrm{~g}$ \\
Galat & $(\mathrm{r}-1)(\mathrm{g}-1)$ & $\mathrm{M} 0$ & $\sigma^{2} \mathrm{e}$ \\
\hline
\end{tabular}

Keterangan: $\mathrm{Db}=$ derajat bebas, $\mathrm{KT}=$ kuadrat tengah, $\mathrm{r}=$ ulangan, $\mathrm{g}=$ perlakuan, $\sigma^{2} \mathrm{e}=$ ragam galat, $\sigma^{2} \mathrm{~g}=$ ragam genetik

Tabel 2. Sidik ragam untuk rancangan perbesaran dalam RKLT

\begin{tabular}{lllll}
\hline Sumber keragaman & $\mathrm{Db}$ & $\mathrm{JK}$ & $\mathrm{KT}$ & $\begin{array}{l}\text { Nilai harapan } \\
\mathrm{E}(\mathrm{KT})\end{array}$ \\
\hline Blok & $\mathrm{r}-1$ & $\mathrm{JKb}$ & $\mathrm{KTb}$ & \\
Genotipe & $(\mathrm{g}+\mathrm{c})-1$ & $\mathrm{JKp}$ & $\mathrm{KTp}$ & \\
$\quad$ check $(\mathrm{c})$ & $\mathrm{c}-1$ & $\mathrm{JKc}$ & $\mathrm{KTc}$ & $\sigma^{2} \mathrm{e}+\mathrm{r}^{2} \mathrm{c}$ \\
$\quad$ geno $(\mathrm{g})$ & $\mathrm{g}-1$ & $\mathrm{JKg}$ & $\mathrm{KTg}$ & $\sigma^{2} \mathrm{e}+\sigma^{2} \mathrm{~g}$ \\
$\quad$ check vs geno & 1 & $\mathrm{JKcvg}$ & $\mathrm{KTcvg}$ & \\
Galat & $((\mathrm{g}+\mathrm{rc})-1)-((\mathrm{g}+\mathrm{c})-1)-(\mathrm{r}-1)$ & $\mathrm{Jke}$ & $\mathrm{Kte}$ & $\sigma^{2} \mathrm{e}$ \\
\hline Total & $(\mathrm{g}+\mathrm{rc})-1$ & $\mathrm{JKt}$ & & \\
\hline
\end{tabular}

Keterangan: $\mathrm{Db}=$ derajat bebas, $\mathrm{JK}=$ jumlah kuadrat, $\mathrm{KT}=$ kuadrat tengah, $\mathrm{r}=$ ulangan, $\mathrm{p}=$ perlakuan, $\mathrm{e}=$ galat,$\sigma^{2} \mathrm{e}=$ ragam galat, $\sigma^{2} \mathrm{c}=$ ragam pembanding, $\sigma^{2} \mathrm{~g}=$ ragam genetik

Penanaman dilakukan dengan sistem tanam benih langsung di lapang dengan menanam dua benih/lubang tanam pada jarak $50 \mathrm{~cm} \times 50 \mathrm{~cm}$. Penjarangan dilakukan pada saat tanaman berumur 2 MST dengan menyisakan satu tanaman terbaik. Apabila benih tidak tumbuh, penyulaman dilakukan pada 1 MST dengan menanam kembali benih pada lubang tanam yang tidak tumbuh tersebut.
Pemupukan diberikan pupuk N 20 $\mathrm{kg} / \mathrm{ha}, \quad \mathrm{P} 40 \mathrm{~kg} / \mathrm{ha}$ dan $\mathrm{K} 40 \mathrm{~kg} / \mathrm{ha}$ (Adisarwanto et al. 1998). Penyiraman, pengendalian gulma dan hama penyakit tanaman dilakukan menyesuaikan keadaan tanaman di lapang. Pemasangan ajir dilakukan saat tanaman berumur 2 MST. Panen dilakukan pada saat polong 80-90\% telah kering (Adisarwanto et al, 1998). 
Pengamatan dilakukan terhadap karakter morfologi berupa karakter kualitatif dan kuantitatif menurut Rif'atunidaudina (2018). Karakter kualitatif meliputi habitus tanaman, tipe tumbuh, tipe perkecambahan, batang, daun, bunga, polong dan biji. Hanya karakter yang berbeda dengan kontrol yang dilaporkan.

Karakter kuantitatif meliputi:

a. Tinggi tanaman, lebar tajuk dan jumlah cabang diukur dan dihitung pada saat tanaman berbunga.

b. Panjang tangkai, panjang daun, dan lebar daun diukur pada saat tanaman berbunga.

c. Umur berbunga, umur panen dan periode panen dihitung saat tanaman berbunga, panen pertama sampai panen terakhir.

d. Panjang polong, jumlah biji/polong, berat 100 biji dan berat biji/tanaman diukur, dihitung dan ditimbang saat panen.

Data yang dihasilkan akan dianalisis ragam dan komponen ragam dan heritabilitas diduga menggunakan dua metode yaitu berdasarkan populasi yang ditanam (Tabel 1) dan diturunkan dari sidik ragam rancangan percobaan (Tabel 2)

a. Berdasarkan populasi yang ditanam, sebagai berikut:

1. Ragam genetik, diduga dari ragam fenotip dikurang ragam lingkungan

$$
\begin{aligned}
\sigma^{2} \mathrm{~g} & =\sigma^{2} \mathrm{p}-\sigma^{2} \mathrm{e} \\
\operatorname{dimana}, \sigma^{2} \mathrm{p} & =\sigma^{2} \mathrm{M} 2 \\
\sigma^{2} \mathrm{e} & =\sigma^{2} \mathrm{M} 0
\end{aligned}
$$

2. Koefisien keragaman genetik (KKG), digunakan untuk menduga luas atau tidaknya keragaman genetik setiap karakter. Menurut Singh dan Chaudhary (1979) nilai KKG dihitung sebagai berikut:

dimana

$$
\mathrm{KKG}=\frac{\sqrt{\sigma 2} g}{\mu} \times 100 \%
$$

$\sigma^{2} \mathrm{~g}=$ ragam genetik $\mu=$ rataan populasi M2

Syukur et al. (2010) membagi koefisien keragaman genetik menjadi tiga yaitu luas $(>20 \%)$, sedang (10$20 \%)$, dan sempit (0-10\%)

3. Heritabilitas arti luas, diduga dari ragam genetik dan ragam fenotip

$\mathrm{h}^{2} \mathrm{bs}=\left(\sigma_{\mathrm{g}}^{2} / \sigma_{\mathrm{p}}^{2}\right) \times 100 \%$
Syukur $\quad$ at mengklasifikasikan nilai duga heritabilitas arti luas sebagai berikut: $\mathrm{h}^{2}{ }_{\mathrm{bs}}>50 \%$ (tinggi), $20 \%<\mathrm{h}^{2}{ }_{\mathrm{bs}} \leq$ $50 \%$ (sedang) dan $\mathrm{h}^{2}$ bs $\leq 20 \%$ (rendah).

b. Berdasarkan sidik ragam rancangan percobaan

Syukur et al. (2010) menyatakan bahwa komponen ragam dan heritabilitas arti luas dapat dianalisis sebagai berikut:

Ragam genetik, diduga dari

$$
\begin{aligned}
& \sigma^{2} \mathrm{~g}=(\mathrm{KTg}-\mathrm{KTe}) / \mathrm{r} \\
& \sigma^{2} \mathrm{e}=\mathrm{KTe} / \mathrm{r} \\
& \sigma^{2} \mathrm{p}=\sigma^{2} \mathrm{~g}+\sigma^{2} \mathrm{e}
\end{aligned}
$$

Heritabilitas arti luas diduga dari

$$
\mathrm{h}^{2}{ }_{\text {bs }}=\left(\sigma_{\mathrm{g}}^{2} / \sigma_{\mathrm{p}}^{2}\right) \times 100 \%
$$

Analisis kekerabatan menggunakan metode Gower dengan metode klaster average linkage menggunakan software PBSTAT CL.

\section{HASIL DAN PEMBAHASAN}

\section{Karakter Kualitatif}

Tanaman kacang tunggak adalah tanaman menyerbuk sendiri dengan genetik yang terpelihara dalam keadaan homozigot sehingga turunan hasil penyerbukan sendiri tersebut akan sama dengan tetuanya kecuali karena adanya mutasi. Mutasi menyebabkan terjadinya perubahan morfologi tanaman yang berbeda dengan tanaman kontrol. Pada tanaman genotip T6503 menunjukkan bahwa semua tanaman tumbuh dengan habitus tegak perdu akan tetapi tanaman tidak menghasilkan bunga dan buah (Gambar 1 b). Hal ini diduga gen atau kromosom pengendali pembungaan 
pada kacang tunggak mengalami mutasi menjadi tidak aktif sehingga bunga tidak muncul. Induksi mutasi iradiasi sinar gamma pada kacang tunggak menghasilkan dua belas tanaman mutan putatif dengan habitus tanaman tegak perdu, tipe tumbuh determinate, pelekatan polong pada pedunkulus tegak, kedudukan tandan semua di atas kanopi dan terjadi keragaman warna daun dan bentuk daun (Gambar $1 \mathrm{c}-\mathrm{n})$.
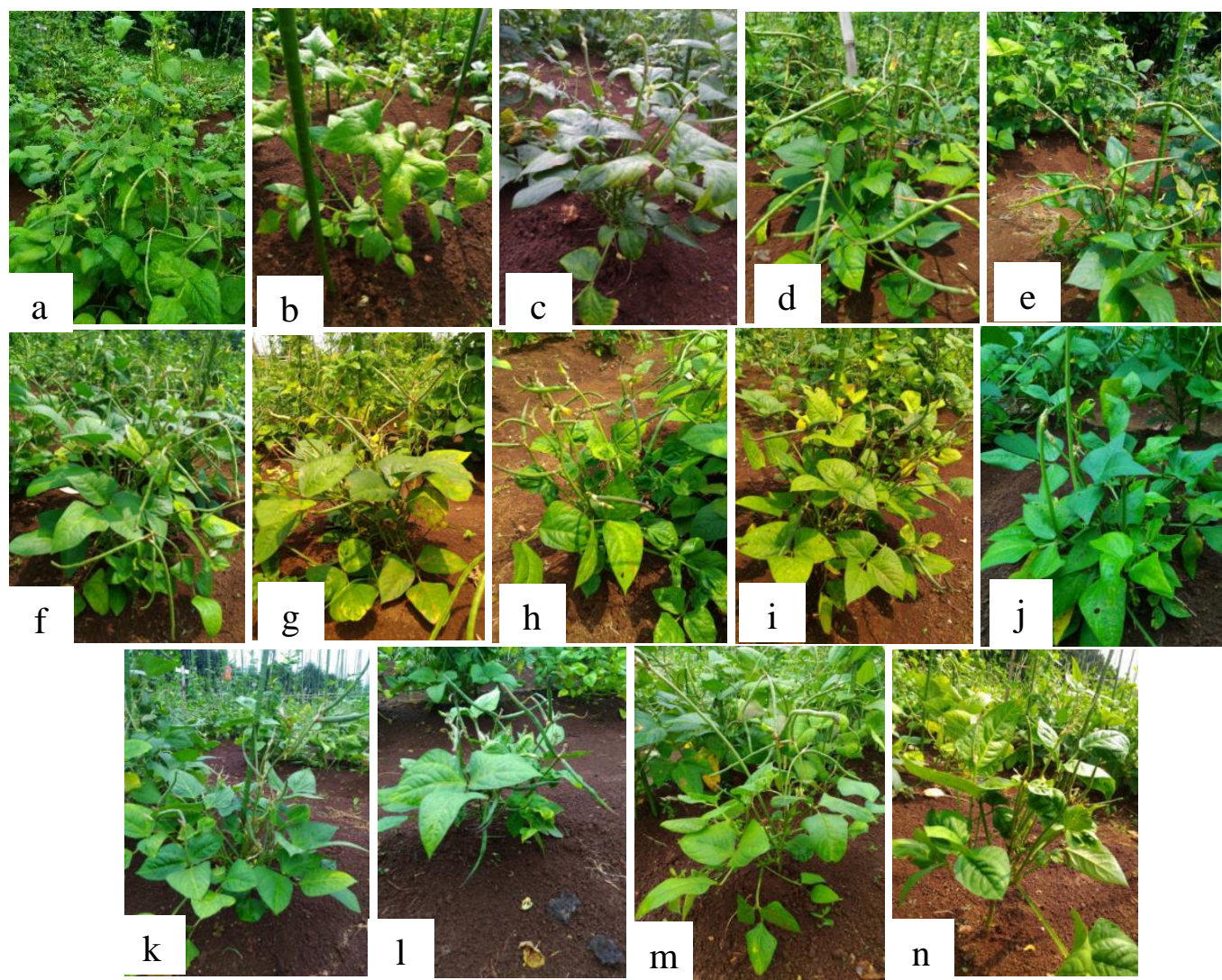

Gambar 1. Keragaan keragaman tanaman kontrol (a) dan mutan putatif kacang tunggak generasi M2 $(b-n)$

Keragaman dapat terjadi pada tingkat spesies yang disebabkan oleh faktor genetik dan lingkungan (Hartati dan Darsana 2015). Terjadinya abnorrnalitas pada populasi mutan menunjukkan bahwa telah terjadi perubahan pada tingkat genorn, kromosom dan DNA atau gen yang sangat besar sehingga proses fisiologis yang dikendalikan secara genetik dalam tanaman menjadi tidak normal dan menimbulkan variasi-variasi genetik baru (Human, 2003).

Herison et al. (2008) menyatakan bahwa secara teoritis mutasi yang terjadi akan bersifat acak ke berhagai kemungkinan. Pada iradiasi terhadap biji, peluang terjadinya mutasi lebih besar pada generasi keturunan menyerbuk sendiri dari biji yang diradiasi, yaitu pada generasi M2. Pada generasi tersebut sudah terjadi segregasi pada lokus-lokus yang mengalami mutasi sehingga peluang munculnya karakter baru akan semakin besar.

Pada genotip T6561 dihasilkan polong dengan ukuran lebih besar dibandingkan polong pada genotip KM4 (Gambar 2). Bertambahnya ukuran polong pada genotip T6561 menjadikan ukuran biji menjadi lebih besar dibandingkan dengan biji pada genotip KM4 (Gambar 3). Bertambahnya ukuran biji pada genotip T6561 terjadi diduga 
karena adanya rongga polong yang lebih besar sehingga biji dapat berkembang menjadi lebih besar.

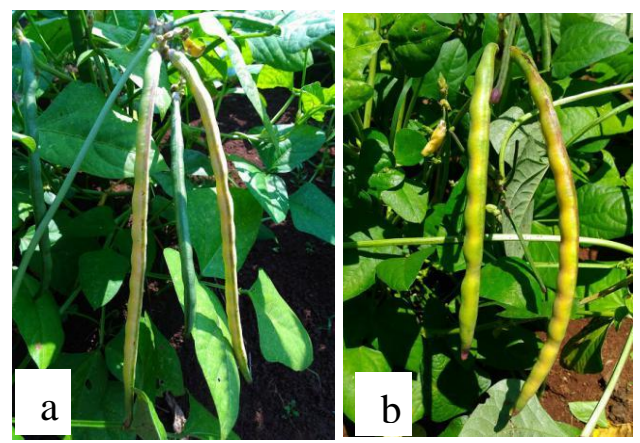

Gambar 2. Keragaan polong kontrol (a) dan mutan putatif (b) kacang tunggak generasi M2

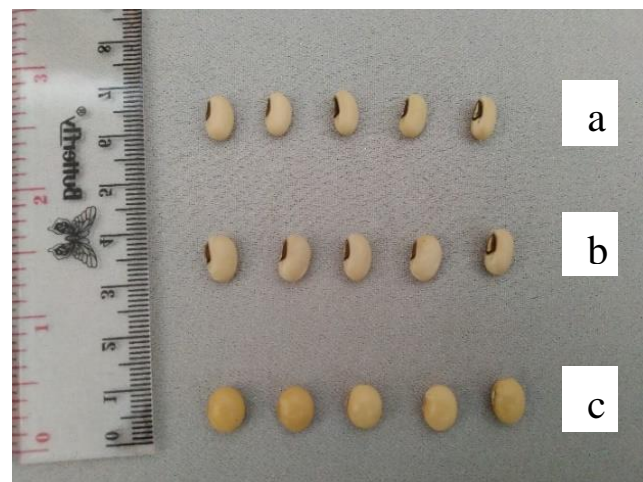

Gambar 3. Keragaan biji KM4 (a), mutan putatif genotip T6561 (b) dan kedelai varietas Grobogan (c)

\section{Analisis Komponen Ragam dan Heritabilitas Karakter Kuantitatif}

Populasi mutan M2 merupakan populasi yang setara dengan populasi F2 pada tanaman hasil persilangan, dimana merupakan populasi dengan keragaman tertinggi. Pada populasi mutan M2 dapat diduga nilai ragam dengan menanam tanaman kontrol (M0) sebagai populasi untuk menduga nilai ragam lingkungan sedangkan populasi mutan M2 dapat digunakan untuk menduga nilai ragam fenotip sehingga nilai ragam genetik dapat dihasilkan dan dapat digunakan untuk menduga nilai heritabilitas arti luas dan koefisien keragaman genetik populasi mutan M2. Nilai duga komponen ragam, heritabilitas arti luas dan koefisien keragaman genetik dapat dilihat secara rinci pada Tabel 3.

Keberhasilan induksi mutasi pada karakter poligenik dapat dilihat dari rataan, koefisien keragaman dan heritabilitas dalam populasi M2 pasca perlakuan mutagen (Sakin 2002). Nilai ragam genetik dan ragam lingkungan menentukan besarnya heritabilitas dan koefisien ragam genetik suatu karakter (Wani dan Khan 2006). Nilai heritabilitas pada karakter panjang tangkai, umur berbunga, jumlah biji/polong, berat 100 biji dan berat biji/tanaman tergolong tinggi, sedangkan pada karakter tinggi tanaman, lebar tajuk, jumlah cabang, panjang daun, lebar daun, periode panen dan panjang polong termasuk dalam katagori sedang. Koefisien keragaman genetik tinggi dihasilkan pada karakter tinggi tanaman, lebar tajuk, periode panen, jumlah biji/polong, berat 100 biji dan berat biji/tanaman (Tabel 3.).

Analisis komponen ragam, heritabilitas arti luas dan koefisien keragaman genetik pada populasi hasil induksi mutasi juga dapat diduga diturunkan dari anova rancangan perbesaran dalam RKLT menggunakan nilai kuadrat tengah genotip dan kuadrat tengah galat. Tabel 4. menunjukkan bahwa nilai heritabilitas tinggi dihasilkan pada karakter lebar daun, umur berbunga, umur panen dan panjang polong, sedangkan nilai heritabilitas sedang dihasilkan pada karakter tinggi tanaman, lebar tajuk, jumlah cabang, panjang daun, periode panen dan berat biji/tanaman. Heritabilitas rendah dihasilkan pada karakter panjang tangkai, jumlah biji/polong dan berat 100 biji. Koefisien keragaman genetik yang tinggi dihasilkan pada karakter tinggi tanaman dan berat biji/tanaman, sedangkan pada karakter lain yang dianalisis menghasilkan koefisien keragaman genetik yang rendah. 
Tabel 3. Analisis komponen ragam, heritabilitas dan koefisien keragaman genetik metode a mutan putatif kacang tunggak generasi M2

\begin{tabular}{lccccc}
\hline Karakter & $\sigma_{\mathrm{p}}^{2}$ & $\sigma^{2}{ }_{\mathrm{e}}$ & $\sigma_{\mathrm{g}}^{2}$ & $\mathrm{~h}^{2}$ bs & $\mathrm{KKG}(\%)$ \\
\hline Tinggi tanaman & 1144.29 & 653.33 & 490.97 & 42.91 & 457.91 \\
Lebar tajuk & 56.64 & 41.60 & 15.04 & 26.55 & 25.03 \\
Jumlah cabang & 0.40 & 0.25 & 0.15 & 36.26 & 3.01 \\
Panjang tangkai & 0.02 & 0.01 & 0.01 & 56.63 & 0.43 \\
Panjang daun & 0.58 & 0.38 & 0.20 & 34.55 & 1.68 \\
Lebar daun & 0.37 & 0.25 & 0.12 & 31.89 & 1.52 \\
Umur berbunga & 6.02 & 1.90 & 4.12 & 68.45 & 10.65 \\
Umur panen & 7.00 & 4.00 & 3.00 & 42.92 & 4.96 \\
Periode panen & 76.09 & 44.90 & 31.19 & 40.99 & 134.87 \\
Panjang polong & 5.09 & 3.85 & 1.24 & 24.33 & 7.84 \\
Jumlah biji/polong & 150.34 & 46.80 & 103.54 & 68.87 & 954.00 \\
berat 100 biji & 5.77 & 1.30 & 4.47 & 77.46 & 32.21 \\
Berat biji/tanaman & 98.92 & 48.52 & 50.41 & 50.96 & 264.59 \\
\hline
\end{tabular}

Tabel 4. Analisis komponen ragam, heritabilitas dan koefisien keragaman genetik metode b mutan putatif kacang tunggak generasi M2

\begin{tabular}{lccccc}
\hline Karakter & $\sigma_{\mathrm{p}}^{2}$ & $\sigma^{2}{ }_{\mathrm{e}}$ & $\sigma_{\mathrm{g}}^{2}$ & $\mathrm{~h}^{2}$ bs & KKG $(\%)$ \\
\hline Tinggi tanaman & 150.82 & 98.56 & 52.26 & 34.65 & 46.62 \\
Lebar tajuk & 8.74 & 4.86 & 3.88 & 44.39 & 6.46 \\
Jumlah cabang & 0.05 & 0.03 & 0.02 & 39.22 & 0.39 \\
Panjang tangkai & 0.85 & 0.69 & 0.16 & 18.80 & 5.16 \\
Panjang daun & 0.09 & 0.07 & 0.02 & 23.26 & 0.17 \\
Lebar daun & 0.07 & 0.02 & 0.05 & 68.49 & 0.65 \\
Umur berbunga & 1.36 & 0.40 & 0.96 & 70.80 & 2.48 \\
Umur panen & 2.61 & 0.40 & 2.21 & 84.74 & 3.65 \\
Periode panen & 9.30 & 7.28 & 2.02 & 21.73 & 8.74 \\
Panjang polong & 1.24 & 0.36 & 0.88 & 70.80 & 5.57 \\
Jumlah biji/polong & 12.51 & 11.63 & 0.88 & 7.03 & 8.07 \\
berat 100 biji & 0.49 & 0.43 & 0.06 & 12.32 & 0.43 \\
Berat biji/tanaman & 14.22 & 9.00 & 5.22 & 36.70 & 27.33 \\
\hline
\end{tabular}

Herawati et al. (2009) menyatakan bahwa nilai koefisien keragaman genetik yang tinggi menandakan karakter yang diamati memiliki keragaman genetik yang luas. Nura et al. (2015) menyatakan bahwa nilai heritabilitas rendah hingga sedang menunjukkan bahwa tingginya pengaruh faktor lingkungan jika dibandingkan dengan faktor genetiknya, sedangkan nilai heritabilitas yang tinggi menunjukkan bahwa pengaruh genetik lebih tinggi jika dibandingkan dengan faktor lingkungan.
Adanya nilai keragaman genetik dan heritabilitas yang tinggi pada karakter tertentu saat generasi M2 memungkinkan dimulainya seleksi pada generasi tersebut. Induksi mutasi melalui iradiasi sinar gamma pada penelitian ini terbukti efektif meningkatkan keragaman genetik pada karakter tinggi tanaman, periode panen, jumlah biji/polong dan berat biji/tanaman kacang tunggak. 


\section{Analisis Kekerabatan}

Hubungan kekerabatan genotip mutan M2 yang dihasilkan dengan metode Gower average linkage ditampilkan dalam bentuk dendogram (Gambar 4.). Semakin rendah tingkat kemiripan maka keragaman semakin besar. Pada tingkat kemiripan 0,23102 genotip mutan M2 kacang tunggak terbagi menjadi empat gerombol. Gerombol I, II, III, dan IV masingmasing terdiri atas $12,1,13$ dan 76 genotip (Gambar 5). Gerombol I terdiri dari 12 genotip dengan habitus tanaman tegak perdu yaitu T6599P, T8028P, T7525P, T7551P, T7520P, T6574P, T6533P, T7058P, T6577P, T6591P, T7062P dan T7069P.

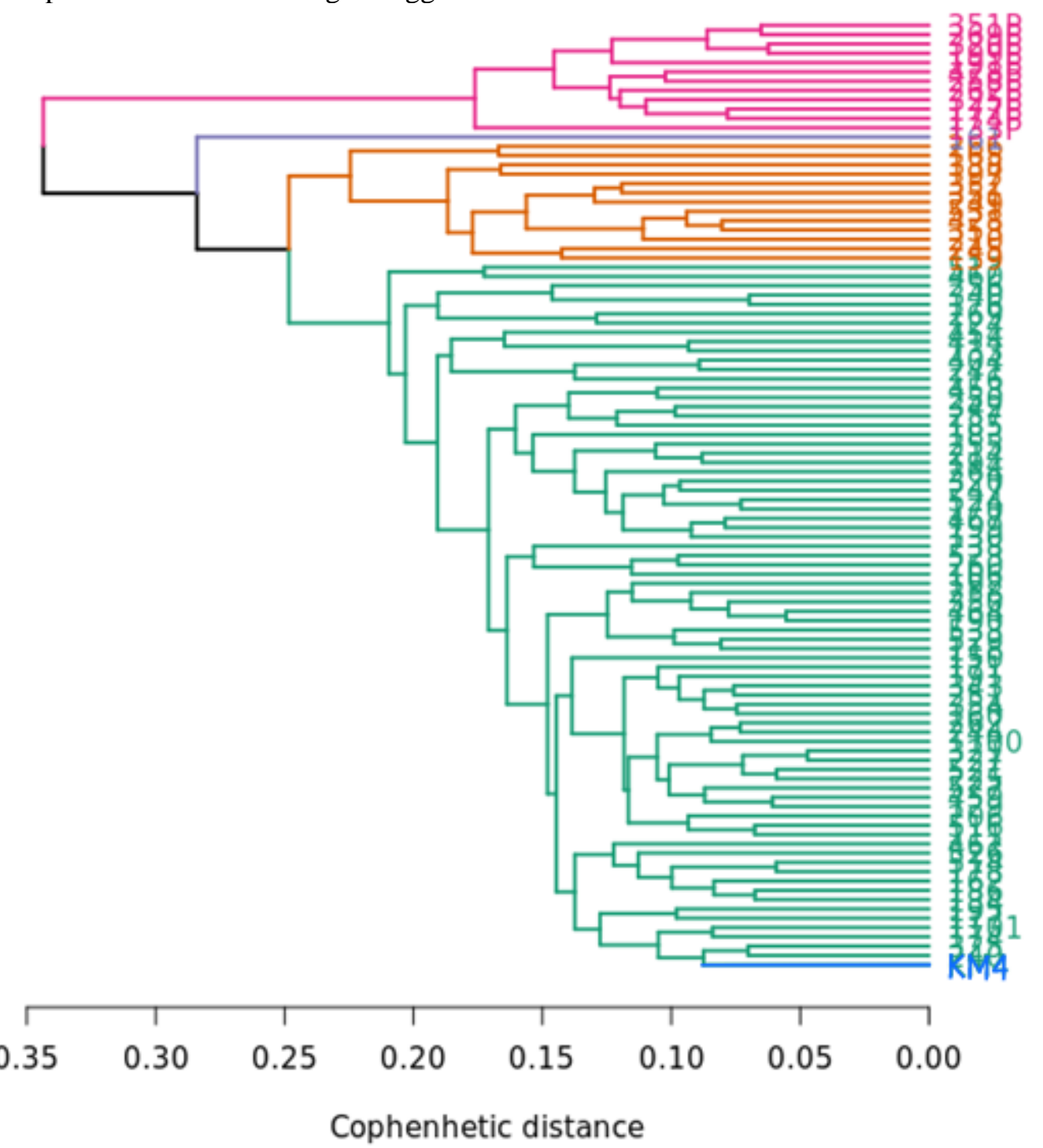

Gambar 4. Dendogram 102 genotip mutan putatif kacang tunggak generasi M2 berdasarkan karakter kualitatif dan kuantitatif

Gerombol II terdiri dari satu genotip yaitu T6561. Gerombol III terdiri dari 13 genotip yaitu T6565, T7553, T8531, T8028, T7552, T7049, T7531, T7066, T6539, T7010, T7538, T6097 dan T7045, dan sisanya sebanyak 76 genotip masuk kedalam gerombol IV termasuk genotip KM4 didalamnya. Keseluruhan perubahan pada galur mutan diduga terjadi akibat mutasi yang menyebabkan proses fisiologis yang dikendalikan secara genetik dalam tanaman menjadi tidak normal dan menimbulkan variasi genetik baru. 
Hasil analisis gerombol dan diagram pencar menunjukkan bahwa pada cophenhetic distance 0,25 atau tingkat kemiripan 25\% dihasilkan 13 genotip mutan yang berbeda dengan tanaman kontrol yaitu genotip T6599P, T8028P, T7525P, T7551P, T7520P, T6574P, T6533P, T7058P, T6577P, T6591P, T7062P, T7069P dan T6561. Analisis kekerabatan oleh Setyowati dan Minantyorini (2016) menghasilkan 106 aksesi kacang tunggak dengan kemiripan 47,16 \%. Suhartina et al. (2016) menghasilkan 52 aksesi kedelai polong coklat muda dengan kemiripan 32,67\% dan 96 aksesi kedelai polong coklat dengan kemiripan 41,17\%. Dengan demikian dapat dinyatakan bahwa induksi mutasi iradiasi sinar gamma dapat meningkatkan keragaman genotip kacang tunggak dan sumber keragaman yang dihasilkan dapat dimanfaatkan lebih lanjut untuk pembentukan varietas unggul baru kacang tunggak.

Noorrohmah et al. (2015) menyatakan bahwa tingkat kemiripan genetik tanaman pada pola pengelompokan keragaman genetik yang terlihat berbeda dengan tanaman yang lain memungkinkan tanaman mengalami akumulasi mutasi spontan yang mengakibatkan terjadinya mutasi delesi. Singh et al., (2008) menyatakan bahwa genotip yang berbeda kelompok dengan jarak genetik yang jauh dapat dimanfaatkan dalam program pemuliaan tanaman untuk mendapatkan keragaman yang luas.

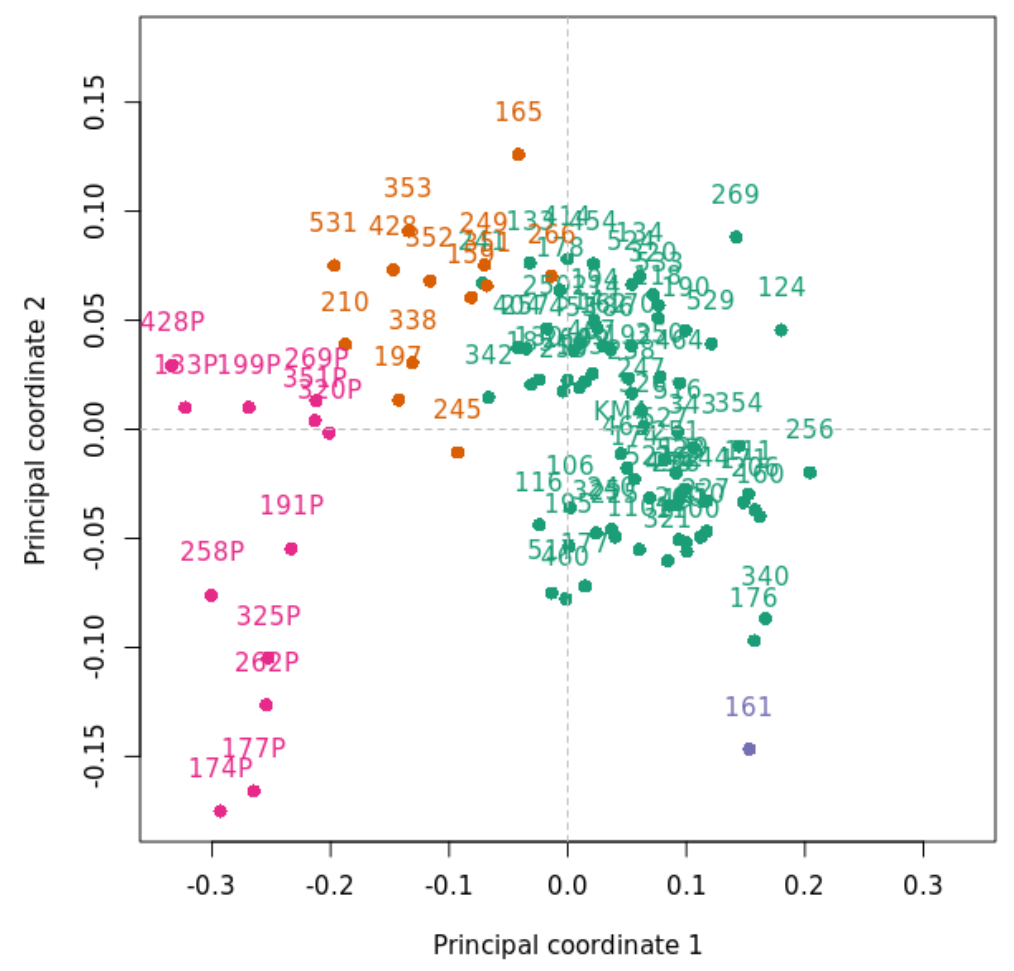

Gambar 5. Diagram pencar 102 genotip mutan kacang tunggak generasi M2

\section{SIMPULAN}

Mutan putatif hasil induksi mutasi iradiasi sinar gamma dapat meningkatkan keragaman pada karakter kualitatif dan kuantitatif kacang tunggak. Keragaman genetik yang tinggi ditunjukkan pada karakter tinggi tanaman, periode panen, jumlah biji/polong dan berat biji/tanaman kacang tunggak dan nilai heritabilitas arti luas yang tinggi dihasilkan pada karakter panjang tangkai, umur berbunga, jumlah biji/polong dan berat 
biji/tanaman kacang tunggak. Hasil analisis kekerabatan menunjukkan tiga belas genotip mutan putatif yang berbeda dengan genotip KM4 yaitu genotipe T6599P, T8028P, T7525P, T7551P, T7520P, T6574P, T6533P, T7058P, T6577P, T6591P, T7062P, T7069P dan T6561.

\section{DAFTAR PUSTAKA}

Adisarwanto T, Riwanodja, Suhartina. 1998. Budi daya tanaman kacang tunggak. Monograf BALITKABI 3: 78-83.

[BKPPP] Badan Ketahanan Pangan dan Pelaksana Penyuluhan. 2014. Data Kandungan Gizi Bahan Pangan dan Olahan Golongan Kacang-kacangan dan Biji-bijian. Yogyakarta (ID): BKPPP Bantul.

Chavan JK, Kadam SS, Salunkhe DK. 1989. Cowpea. In Salunkhe DK, Kadam SS (Eds) CRC Handbook of World Food Legumes: Nutritional Chemistry, Processing Technology and Utilization, vol 2. CRC Press, Inc. Boca Raton, Florida : 1-22

Federer WT. 1994. Augmented Experiment Designs with Recofery of Interblock and Intervariety Information. Itacha (US): Cornell University.

Hartati S, Darsana L. 2015. Karakterisasi anggrek alam secara morfologi dalam rangka pelestarian plasma nutfah. J. Agron Indonesia. 43 (2): 133-139.

Herawati R, Purwoko BS, Dewi IS. 2009. Keragaman genetik dan karakter agronomi galur haploid ganda padi gogo dengan sifat-sifat tipe baru hasil kultur antera. $J$ Agron Indonesia. 37(2): 87-94.

Herison K, Rustikawati, Sutjahjo SH, Aisyah SI. 2008. Induksi mutasi melalui iradiasi sinar gamma terhadap benih untuk meningkatkan keragaman populasi dasar Jagung (Zea mays L). J Akta Agrosia 11(1): 57-62.

Human S. 2003. Peran iptek nuklir dalam pemuliaan tanaman untuk mendukung industri pertanian. Prosiding Pertemuan dan Presentasi Ilmiah Penelitian Dasar Ilmu Pengetahuan dan Teknologi Nuklir P3TM BATAN. Yogyakarta.

[IAEA] International Atomic Energy Agency. 2003. Mutation Breeding News Letter No.46. IAEA, Vienna, Austria.

Ishak. 2012. Sifat agronomi, heritabilitas dan interaksi $\mathrm{G} \times \mathrm{E}$ galur mutan padi gogo (Oryza sativa L.). J. Agron. Indonesia 40: 105-111.

Noorrohmah, Sobir, Efendi D. 2015. Analisis keragaman genetik manggis dalam satupohon. J. Hort. 25(2): 106-112.

Nura, Syukur M, Khumaida N, Widodo. 2015. Radiosensitivitas dan heritabilitas ketahanan terhadap penyakit antraknosa pada tiga populasi cabai yang diinduksi iradiasi sinar gamma. J. Agron. Indonesia 43(3): 201-206.

Rif'atunidaudina R. 2018. Kajian Keanekaragaman Morfologi, Metabolit Primer dan Molekuler Sumber Daya Genetik Kacangkacangan Underutilized Indonesia. Tesis. Institut Pertanian Bogor.

Rosida EF, Hardiyanti Q, Murtiningsih. 2013. Kajian dampak substitusi kacang tunggak pada kualitas fisik dan kimia tahu. J. Tek. Pangan 5(2): 138-149.

Sakin MA, Yildrim A, Gokmen S. 2004. The evaluation of agronomic traits of durum wheat (Triticum durum Desf.) mutants. Pak J. Biol Sci. 7(4): 571-576.

Sigh S, Pradhan SK, Virk P. 2008. Genetic divergence in new plant type rice under shallow lowland ecosistem. SABRAO 40(1): 1-8.

Singh RK, Chaudhary BD. 1979. Biometrical Methods in Quantitative Genetic Analysis. New Delhi (IN): Ludhiana Kalyani Pub.

Suhartina, Hapsari RT, Purwantoro. 2016. Keragaman plasma nutfah kedelai berdasarkan keragaan 
karakter morfo-agronomis. Bul. Plasma Nutfah 22(2): 109-118.

Syahril M. 2018. Rancangan bersekat (augmented design) untuk penelitian bidang pemuliaan tanaman. J. Penelitian 5(1): 63-66.

Syukur M, Sujiprihati S, Siregar A. 2010. Pendugaan parameter genetik beberapa karakter agronomi cabai F4 dan evaluasi daya hasilnya menggunakan rancangan perbesaran (Augmented design). J. Agrotropika 15: 9-16.
Wani MR, Khan S. 2006. Estimates of genetic variability in mutated populations and the scope of selection for yield attributes in Vigna radiata (L.) Wilczek. Egypt J. Biol. 8: 1-6.

Yunianti R, Sastrosumarjo S, Sujiprihati S, Surahman M, Hidayat SH. 2010. Kriteria seleksi untuk perakitan varietas cabai tahan Phytophthora capsici Leonian. $J$. Agron. Indonesia 38: 122. 